右略二量に喿細た分長吉

のしな氣すか。の週田

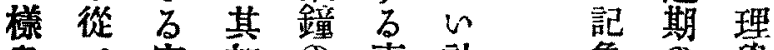

五密加 事計象 $D$ 學

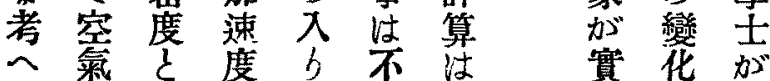

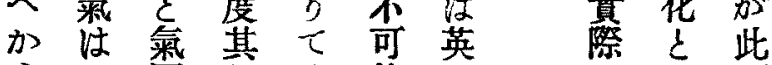

万内呩和

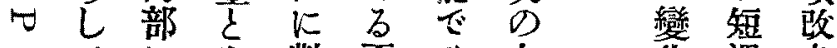

1 元 $K$ 對石 8 方

計於持守油

算て

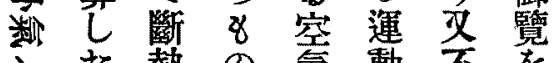

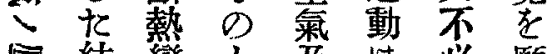

結變之症必願

粱华し石少要的

I次を、油导でた

॥

句結李等抵分名、

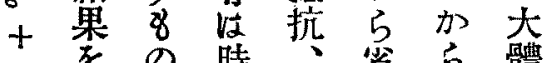

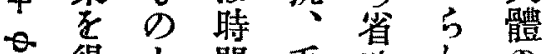

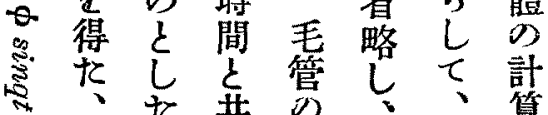

灻共窎、、算

作及外合

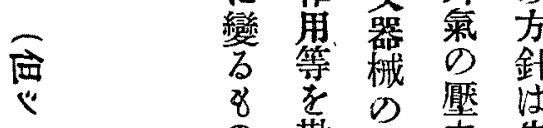

化 崌

に期 せ

比方

L 變 让

$\tau$ 化 证

$\varepsilon \varepsilon$ 微

の 加厚

位 計

の K $k$

位 依 就

相 b w

$D \div \tau$

變竞

加變 號

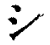

$1^{3}$

ダ

イ

ある を

万胃

等文占

勘摩方先吕府其

事屬 倍

知艺萃 藤

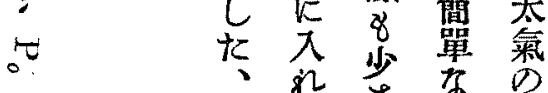

แl

些

器望学等

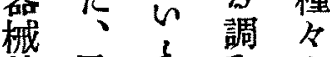

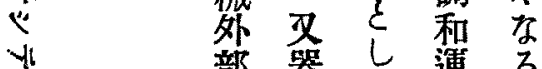

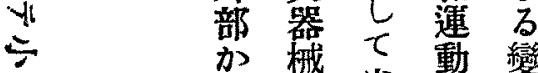

$+$

$\Xi$

ら丙省峳變

部略手

熱 0 乙 万 就

空た者き

真柔氣范气

苦皆鏱し文

省荺質次吟

b外

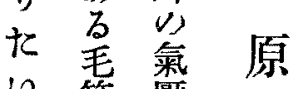

心管 壓

$\varepsilon$ 注

思ど戀

灾方化

靠 の

計㮔

算働 類 平

古例

又合

見ぺば 

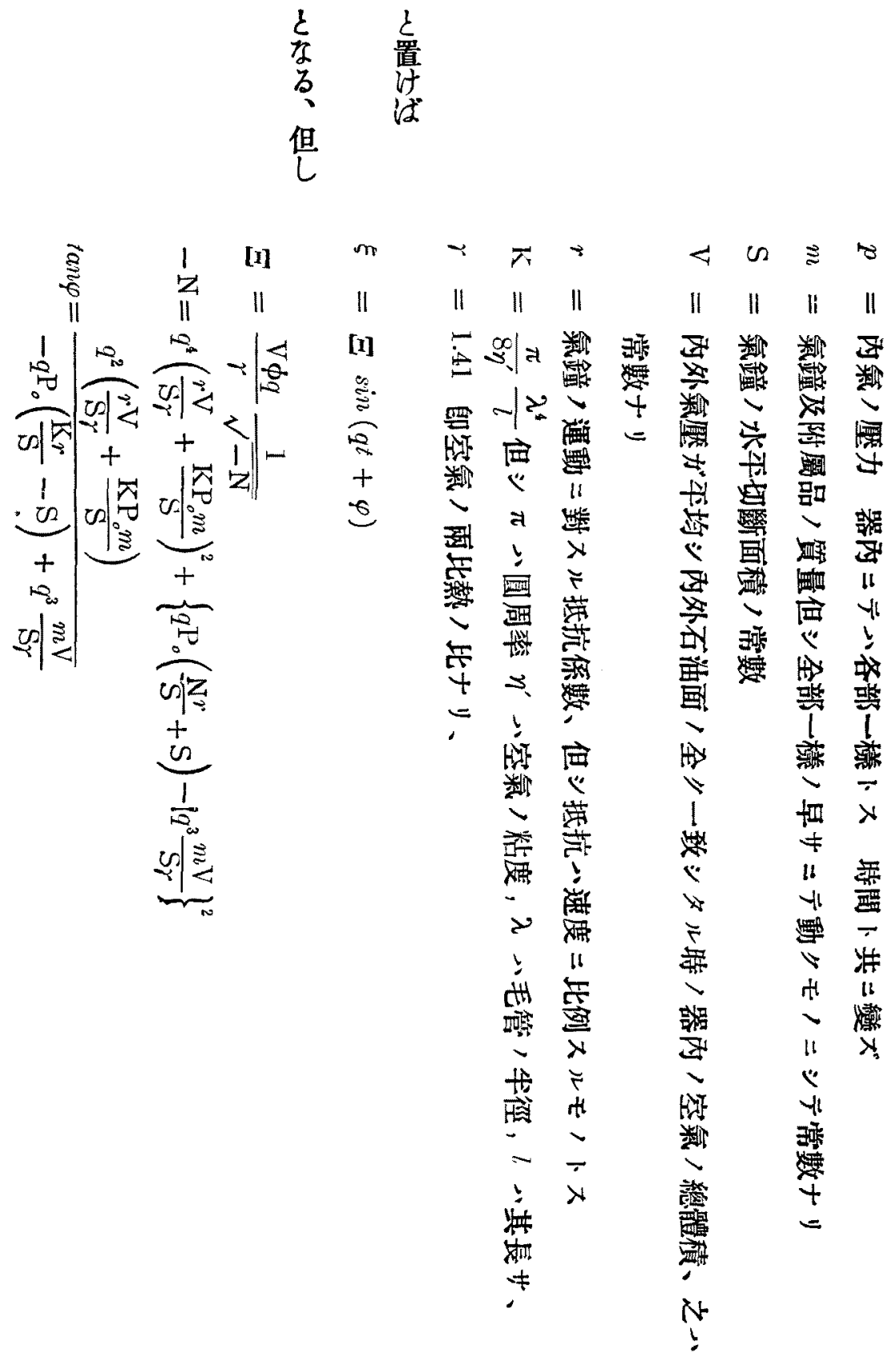


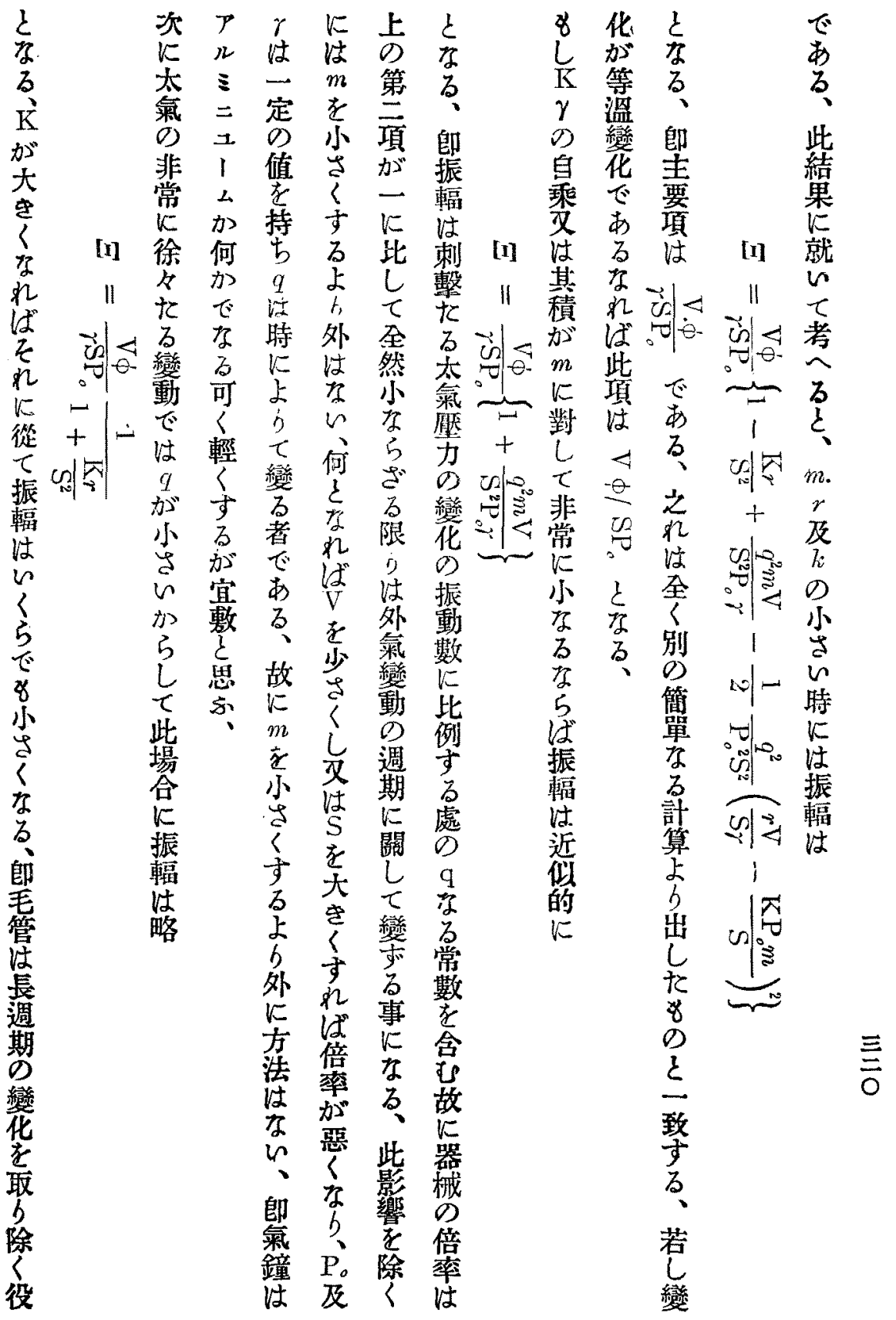




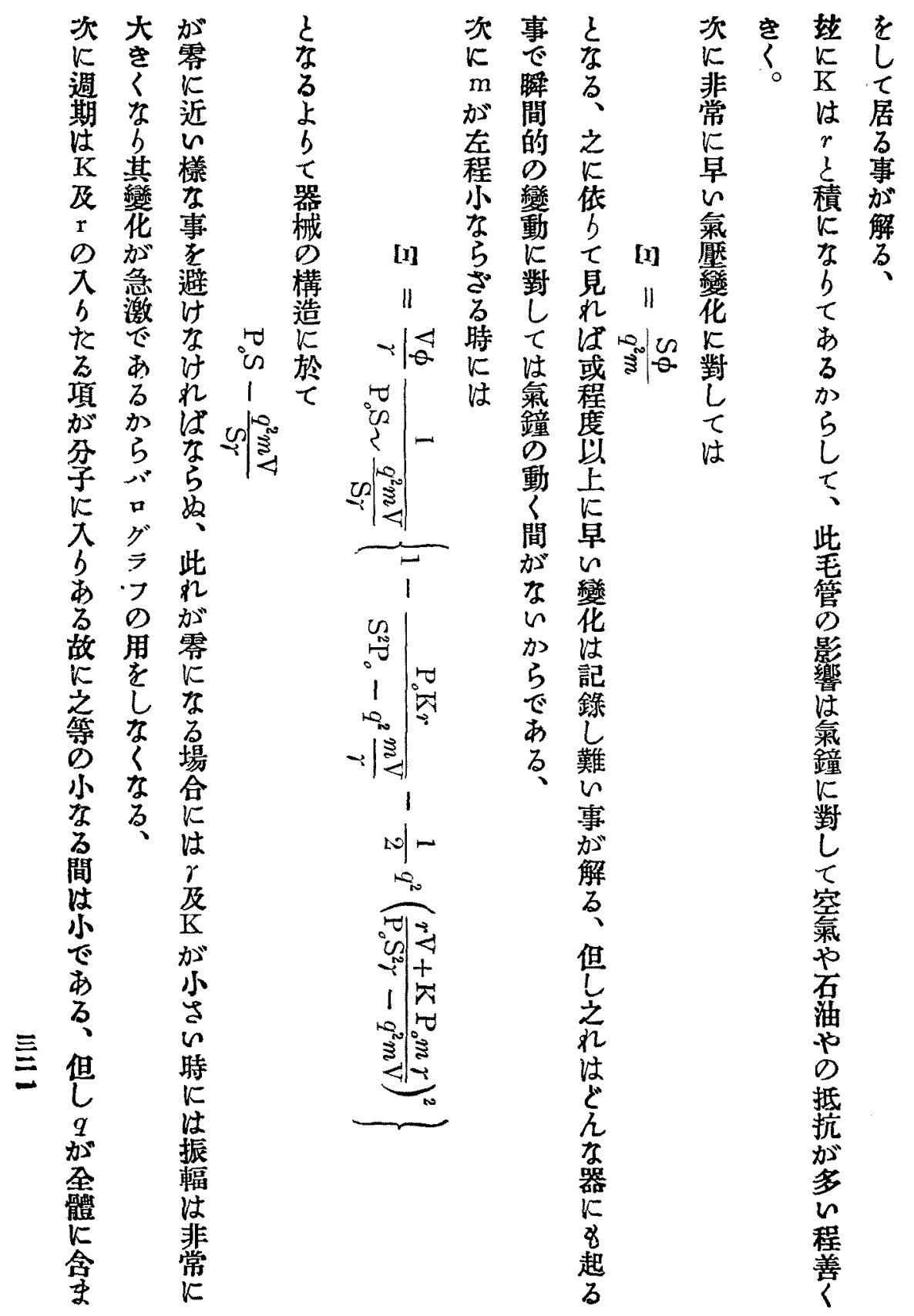


跂震、分野 8 8 動 緒、

器源、三年東 の 然計 言、

物位、三亲方测八

の置秒よが大に月

轉子小此尔依十

落震 b 8 些る る

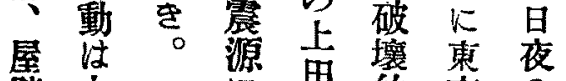

壁上卡思的京の

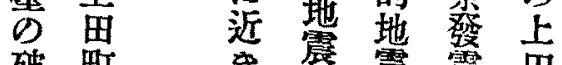

破町拿震震画

損 $心$ を時 地

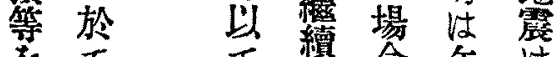

它文絓 合午性

生最篮間に後長

造 8

3 强

江

過b

势

而基

攵 $\frac{z}{\tau}$

碑 8

類 䃪

加翼

動 程

の 度

為注

め達

䔟逢

動

せ 微

3 少

は劣

多当

社圭

北

微 装

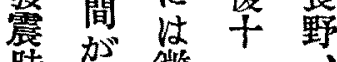

侍此徽㭙

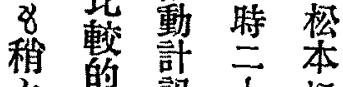

照記干比

智贫分

婪總吾暧

同? 綵四感

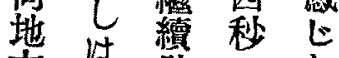

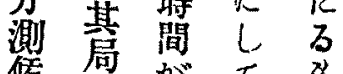

候局部分

乺的㭙震東大

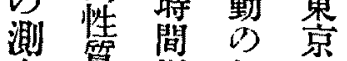

定罗總员

蛋琵數螕应森

れ家特特無

年名法感房

後章約势

泀旁吾吉

时察常分:

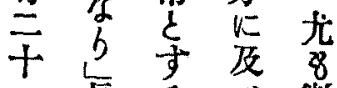

二長名心微
早基象放

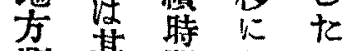

浩間間

十尔名十
賞以器れ

累上械厂

存要

奢占善百

老名加

用工和

大曲構名乙

正造 $k \tau$

事在此

加注出方

出意承泩

承专倍

八|

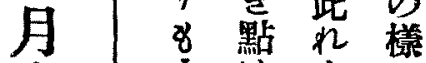

小壮老比

出 小略

々承学定

t苾于

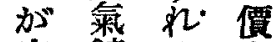

宜鐘

敷亘㝡 几附敷

屬的事

品 此

觜不

輕 に能

人注

寸 $r$ 變

及 及

事 $m$ D

でを種

あ 小 類

冬掏

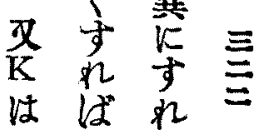

目占济

的 $心$ 變

次痤

㸝名

滴憼 


\section{ON THE THEORY OF THE SHAW-DINES MICROBAROGRAPH.}

BY

\section{S. FUJIWHARA.}

1. Introduction.-In the theory of their microbarograph, Dr. Shaw and Mr. Dines propounded the statical theory, assuming that in the closed vessel containing air the isothermal change of air takes place. ${ }^{(1)}$

One of the most important conditions in constructing this microbarograph is that the vessel must be enclosed in nonconducting walls for heat, since the temperature variation of air within, due to introduction of heat from the outwards, seriously

cts the air-pressure in the vessel, and makes the instrument almost useless. Another important point is that, it has a construction to record the comparatively rapid variation of the atmospheric pressure, which will cause an adiabatic change of the air in the vessel. This consideration leads me to develop a dynamical and adiabatic theory of the microbarograph.

2. Construction.-The construction of the instrument is shown diagrammatically in fig, I. A is an air vessel with a comparatively large volume. The walls of $\mathrm{A}$ are protected from the heat invasion from the outwards with some nonconductive materials of heat. $T_{1}$ and $T_{2}$ are tubes of comparatively great diameter. $c_{1} c_{2}$ is a capillary tube which serves to obliterate the effect of the slow, but not small variations of the atmospheric

(r) W. N. Shaw and W. H. Dines: The study of the Minor fluctuations of atmospheric pressure. Quarterly Journal of the Royal Met. Soci. January, Igo5. p. $39-52$. 
pressure upon the instrument. $B$ is a belljar floating in a light liquid, say petrolium oil, which is kept in a cylindrical vessel V. If

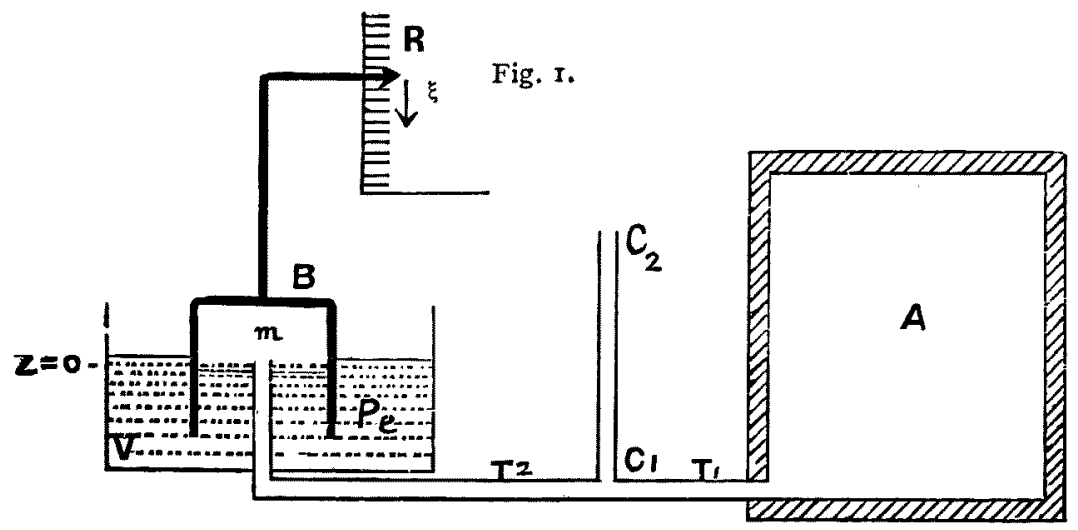

the atmospheric pressure increase or decrease in the outside, then the belljar is to be pushed down or pulled up and the amount of its movement is to be recorded with some magnification on a rotating cylinder $\mathrm{R}$.

3. Equations.-Let

$\mathrm{P}=$ External pressure ;

$p=$ Internal pressure (assumed to be uniform at every part);

$m=$ Mass of the moving part of the belljar and its attachments ;

$\mathrm{S}=$ The sectional area of the belljar;

$\xi=$ Displacement of the belljar from its initial neutral position.

Then the equation of motion of the belljar becomes

$$
m \frac{d^{2} \xi}{d t^{2}}=(\mathrm{P}-p) \mathrm{S}-r \frac{d \xi}{d t} \mp f,
$$

where $r$ denotes resistance, and $f$ friction.

Let $u, v, w$ be the components of the velocity in the liquid 


\section{$-51-$}

then we have, as the equation of continuity

$$
\frac{\partial u}{\partial x}+\frac{\partial v}{\partial y}+\frac{\partial w}{\partial z}=0
$$

or if we assume that the velocity potential exists, then the equation becomes

$$
\frac{\partial^{2} \phi}{\partial x^{2}}+\frac{\partial^{2} \phi}{\partial y^{2}}+\frac{\partial^{2} \phi}{\partial z^{2}}=0
$$

Suppose that the apparatus is initially in the state of equilibrium, so that there is no movement of the liquid as well as the belljar at $t=0$, and the internal and external surface of the liquid are in the same level at that moment $i . e$. we have as the initial conditions.

$$
\xi=\eta=\zeta=0, u=v=w=0 \text { at } t=0,
$$

where $\eta$ and $\zeta$ denote the heights of the surface of the liquid out and in the bell.

As the boundary conditions we have

$$
u=v=w=0 \quad \text { at } \quad r=\mathrm{R},
$$

that is on the wall of the vessel; ( $r$ denotes the radial distance from the center of the Belljar);

$$
u=v=w=0 \text { at } z=\mathrm{d} \text {. }
$$

$i$. e. at the bottom of the vessel;

$$
u=v=w=0 \text { at }
$$

i.e. at the wall of the pipe $\mathrm{T}_{2}$

$$
u=v=w=0 \text { at } r=a, \stackrel{\eta}{\xi}>z>\xi+b .
$$

$i . e$. on the wall of the belljar ;

$$
w=\frac{d \eta}{d t}, \frac{\mathrm{P}}{\rho^{\prime}}=-g \eta-\frac{\partial \phi}{\partial t}-\frac{1}{2} w^{2} .
$$

at $a<r<\mathrm{R}, z=\eta i$.e. at the external free surface of the liquid (where $\rho^{\prime}$ denotes the density of the liquid) and 


$$
\begin{gathered}
-52- \\
w=\frac{d \zeta}{d t}, \quad \frac{p}{\rho^{\prime}}=-g \zeta-\frac{\partial \phi}{\partial t}-\frac{1}{2} w^{2}
\end{gathered}
$$

at $c<r<a, z=\zeta i . e$, at the inner free surface of the liquid.

The equation of motion for the liquid is

$$
\frac{p^{\prime}}{\rho^{\prime}}=-g z-\frac{\partial \phi}{\partial t}-\frac{1}{2} \mathrm{U}^{2}
$$

where $p^{\prime}$ and $\mathrm{U}$ denote the pressure in and the velocity of the liquid.

The total mass $M$ of the air enclosed in the instrument $i . e$. in the jar, tubes and in the air vessel may be put as

$$
\mathrm{M}=\rho\{\mathrm{V}-\mathrm{S}(\xi+\zeta)\}
$$

where $\rho$ is the density of air within, which may be approximately assumed to be uniform and $\mathrm{V}$ denotes the whole volume of air within, in the initial state. We shall have, by differentiating the above formula,

$$
d \mathbf{M}=d \rho\{\mathrm{V}-\mathrm{S}(\xi+\zeta)\}-\rho \mathrm{S}(d \xi+d \xi) \ldots \ldots \ldots \ldots(18 . \ldots \ldots
$$

The mass of air coming into the instrument through the capillary tube $c_{1} c_{2}$ in a time interval $\mathrm{dt}$ is, according to $\mathrm{O}$. E. Meyer

$$
k(\mathrm{P}-p) \rho d t,
$$

where

$$
l_{i}=\frac{\pi}{8 \eta^{1}} \frac{\lambda^{4}}{l}
$$

in which $\eta^{1}$ is the viscosity of air, $\lambda$ the radius of the capillary tube and $l$ is its length.

Hence we shall have by equating (13) and (14)

$$
d \rho\{\mathrm{V}-\mathrm{S}(\xi+\zeta)\}-\rho \mathrm{S}(d \xi+d \zeta)=u(\mathrm{P}-p) ; d t \ldots
$$

If the air undergo the adiabatic change then

$$
\frac{d p}{p}=r \frac{d \rho}{\rho},
$$

where $\gamma$ is the ratio of the two specific heats of air. 
But if it be the isothermal change, then

$$
\frac{d p}{p}=\frac{d \rho}{\rho} \ldots
$$

I shall improve the equation (15) in near future, applying the theory of resonators.

4. Statical theory.-Since the acceleration, resistance and friction of the belljar are very small we may assume, as the first approximation,

$$
\mathrm{P}=p \text { or } d \mathrm{P}=d p
$$

In this case we have to neglect the effect of the capillary tube and to put $x=0$. Then from (8), (9) and $(18)$, we get $\eta=\zeta=0$, and hence there is no sensible motion in the liquid. Thus equation (15) becomes

$$
d \rho\{\mathrm{V}-\xi \mathrm{S}\}-\rho \mathrm{S} d \xi=0
$$

When the change goes on adiapatically then we have, by introducing (16) into the above equation,

$$
\frac{1}{\gamma} \frac{d p}{p}=\frac{\mathrm{S} d \xi}{\mathrm{V}-\xi \mathrm{S}} \text {. }
$$

If we neglect $\xi \mathrm{S}$ comparing with $\mathrm{V}$, then

$$
d \xi=\frac{1}{r} \frac{\mathrm{V}}{\mathrm{S}} \frac{d p}{p} \ldots
$$

On the contrary, if the change be isothermal, we shall have

$$
\frac{d p}{p}=\frac{\mathrm{S} d \xi}{\mathrm{V}-\xi \mathrm{S}}
$$

or as in the former case,

$$
d \xi=\frac{\mathrm{V} d p}{\mathrm{~S}} \frac{d p}{p} \ldots
$$

This result agrees with that obtained by ${ }^{(1)}$ Dr. Shaw and

(1) Loc. cit. 
Dines.

5. Dynamical Theory.-As the second approximation we shall retain $m, r$ and $\varkappa$, but shall neglect the friction and the motion of the liquid in the vessel. The equations becomes in this case

$$
\begin{aligned}
& m \frac{d^{2} \xi}{d t^{2}}=(\mathrm{P}-p) \mathrm{S}-r \frac{d \xi}{d t}, \\
& d \rho(\mathrm{V}-\xi \mathrm{S})-\rho \mathrm{S} d \xi=k \rho(\mathrm{P}-p) d t .
\end{aligned}
$$

If the change be adiabatic, then

$$
\frac{d \rho}{\rho}=\frac{1}{r} \frac{d p}{p}
$$

Eliminating $p$ and $\rho$ between these equations we have

$$
\begin{gathered}
\frac{1}{r}\left(\frac{d \mathrm{P}}{d t}-\frac{r}{\mathrm{~S}} \frac{d^{2 \xi} \xi}{d t^{2}}-\frac{m}{\mathrm{~S}} \frac{d^{3} \xi}{d t^{3}}\right)(\mathrm{V}-\xi \mathrm{S})-\mathrm{S} \frac{d \xi}{d t}\left(\mathrm{P}-\frac{r}{\mathrm{~S}} \frac{d \xi}{d t}-\frac{m}{\mathrm{~S}} \frac{d^{2} \xi}{d t^{2}}\right)= \\
=x\left(\frac{m}{\mathrm{~S}} \frac{d^{2} \xi}{d t^{2}}+\frac{r}{\mathrm{~S}} \frac{d \xi}{d t}\right)\left(\mathrm{P}-\frac{r}{\mathrm{~S}} \frac{d \xi}{d t}-\frac{m}{\mathrm{~S}} \frac{d^{2} \xi}{d t^{2}}\right)
\end{gathered}
$$

Since $\quad \xi, \frac{d \xi}{d t}, \frac{d^{2} \xi}{d t^{2}}, \frac{d^{3} \xi}{d t^{3}}$ are small, we may safely neglect the squares and products of these terms, and then we get

$$
\begin{array}{r}
\frac{\mathrm{V}}{r}\left(\frac{d \mathrm{P}}{d t}-\frac{r}{\mathrm{~S}} \frac{d^{2 \xi}}{d t^{2}}-\frac{m}{\mathrm{~S}} \frac{d^{3} \xi}{d t^{3}}\right)-\mathrm{SP} \frac{d \xi}{d t}= \\
\quad=x \mathrm{P}\left(\frac{r}{\mathrm{~S}} \frac{d \xi}{d t}+\frac{m}{\mathrm{~S}} \frac{d^{2} \xi}{d t^{2}}\right) \ldots \ldots \ldots \ldots \ldots
\end{array}
$$

Suppose that the barometric change which takes place in the outside of the apparatus is of a simple harmonic type, then we have

$$
\mathrm{P}=\mathrm{P}_{0}+\phi \sin q t, \ldots
$$

in which $\phi$ is very small compared with $P_{0}$.

Again neglecting small quantities of the second order we have

$$
\frac{m \mathrm{~V}}{\mathrm{~S} \gamma} \frac{d^{3} \xi}{d t^{3}}+\left(\frac{r \mathrm{~V}}{\mathrm{~S} \gamma}+\frac{k \mathrm{P}_{0} m}{\mathrm{~S}}\right) \frac{d^{2} \xi}{d t^{2}}+\left(\frac{k r}{\mathrm{~S}}+\mathrm{S}\right) \mathrm{P}_{0} \frac{d \xi}{d t}=\frac{\mathrm{V}}{\gamma} q \phi \cos q t .
$$


Assume

$$
\xi=\mathrm{A} \sin q t+\mathrm{B} \cos q t,
$$

where $A$ and $B$ are constants to be determined.

Introduce this into the above equation, and equate coefficients of sinqt and $\cos q t$, then we have

$$
\begin{aligned}
& \mathrm{B} q^{3} \frac{m \mathrm{~V}}{\mathrm{~S} r}-\mathrm{A} q^{2}\left(\frac{r \mathrm{~V}}{\mathrm{~S} r}+\frac{k \mathrm{P}_{0} m}{\mathrm{~S}}\right)-\mathrm{B} q\left(\frac{k r}{\mathrm{~S}}+\mathrm{S}\right) \mathrm{P}_{0}=0 ; \\
& -\mathrm{A} q^{3} \frac{m \mathrm{~V}}{\mathrm{~S} r}-\mathrm{B} q^{2}\left(\frac{r \mathrm{~V}}{\mathrm{~S} \gamma}+\frac{k \mathrm{P}_{0} m}{\mathrm{~S}}\right)+\mathrm{A} q\left(\frac{k r}{\mathrm{~S}}+\mathrm{S}\right) \mathrm{P}_{0}=\frac{\mathrm{V} \phi}{r} q .
\end{aligned}
$$

From these we get

where

$$
\begin{aligned}
& \mathrm{A}=\frac{\mathrm{M}_{1}}{\mathrm{~N}} \frac{\mathrm{V} \psi q}{r}, \\
& \mathrm{~B}=\frac{\mathrm{M}_{2}}{\mathrm{~N}} \frac{\mathrm{V} \phi q}{r},
\end{aligned}
$$

$$
\begin{aligned}
& \mathrm{M}_{1}=-q \mathrm{P}_{0}\left(\frac{k r}{\mathrm{~S}}+\mathrm{S}\right)+q^{3} \frac{m \mathrm{~V}}{\mathrm{~S} r}, \\
& \mathrm{M}_{2}=q^{2}\left(\frac{r \mathrm{~V}}{\mathrm{~S} r}+\frac{k \mathrm{P}_{0} m}{\mathrm{~S}}\right), \\
& \mathrm{N}=-q^{4}\left(\frac{r \mathrm{~V}}{\mathrm{~S} r}+\frac{k \mathrm{P}_{0} m}{\mathrm{~S}}\right)^{2}-\left\{q \mathrm{P}_{0}\left(\frac{k r}{\mathrm{~S}}+\mathrm{S}\right)-q^{3} \frac{m \mathrm{~V}}{\mathrm{~S} \gamma}\right\}^{2} .
\end{aligned}
$$

If $m=r=k=0$, then we have

$$
\mathrm{A}=\frac{\mathrm{V} \phi}{\mathrm{Sr} \mathrm{P}_{0}}, \quad \mathrm{~B}=0,
$$

Hence

$$
\begin{aligned}
\xi & =\frac{\mathrm{V}}{\gamma \mathrm{SP}_{0}} \phi \sin q t, \\
\text { or } \quad d \xi & =\frac{\mathrm{V}}{\gamma \mathrm{SP}_{0}} q \phi \cos q t \mathrm{dt}=\frac{\mathrm{V}}{\gamma \mathrm{SP}_{0}} d \mathrm{P},
\end{aligned}
$$

which coincides with the results obtained in the last paragraph.

6. The amplitude $\Xi$ of the variation of $\xi$ becomes 


$$
\Xi=\sqrt{\mathrm{A}^{2}+\mathrm{B}^{2}}=\frac{\mathrm{V} \phi q}{\gamma} \frac{1}{\sqrt{-\mathrm{IN}}} .
$$

If $m, r$ and $x$ be small then

$$
\Xi=\frac{\mathrm{V} \phi}{\gamma \mathrm{SP}_{0}}\left\{1-\frac{u r}{\mathrm{~S}^{2}}+\frac{q^{2} m \mathrm{~V}}{\mathrm{~S}^{2} \mathrm{P}_{0} r}-\frac{1}{2} \frac{q^{2}}{\mathrm{P}_{0}^{2} \mathrm{~S}^{2}}\left(\frac{r \mathrm{~V}}{\mathrm{~S}_{\gamma}}-\frac{x \mathrm{P}_{0} m}{\mathrm{~S}}\right)^{2}\right\} .
$$

If $\varkappa r, r^{2}$ and $\varkappa^{2}$ are small compared with $m$, then we shall have

$$
\Xi=\frac{\mathrm{V} \phi}{\gamma \mathrm{SP}_{0}}\left\{1+\frac{q^{2} m \mathrm{~V}}{\mathrm{~S}^{2} \mathrm{P}_{0} \gamma}\right\}
$$

Since the correction term for $\Xi$ contains $q$, the multiplication of the instrument depends on the exciting disturbance in such a manner that, for the larger value of $q i$ i.e. for the more rapid barometric change, we shall have the greater multiplication and vice versa.

For a very slow barometric change, i.e. for a very small value of $q,-\mathrm{N}$ becomes

$$
-\mathrm{N}=\left\{q \mathrm{P}_{0}\left(\frac{\mu r}{\mathrm{~S}}+\mathrm{S}\right)\right\}^{2}
$$

And hence

$$
\Xi=\frac{\mathrm{V} \phi q}{r} \frac{1}{q \mathrm{P}_{0}\left(\mathrm{~S}+\frac{\varkappa r}{\mathrm{~S}}\right)}=\frac{1}{r} \frac{\mathrm{V}}{\mathrm{S}} \frac{\phi}{\mathrm{P}_{0}} \frac{1}{\left(1+\frac{\varkappa r}{\mathrm{~S}^{2}}\right)}
$$

This indicates clearly the part played by the capillary tube, that is, for the slow barometric change, the corresponding movement of the recording pen becomes small as $u$ increases, or in the other words, the less multiplication for the greater flow of air through the capillary tube. It is also seen from the above formula that the action of the capillary tube is more efficient for the greater value of $r$, i.e. damping action of the liquid to the belljar gives an assistance to the fainting action of the capillary tube.

On the contrary, when $q$ is very great that is when the baro- 
metric change is very rapid, then $-\mathrm{N}$ becomes

$$
\sqrt{-\mathrm{N}}=q^{3} \frac{\mathrm{mV}}{\mathrm{S} \gamma}
$$

and hence

$$
\boldsymbol{\Xi}=\frac{\mathrm{V} \phi q}{\gamma} \frac{\mathrm{S} \gamma}{q^{3} m \mathrm{~V}}=\frac{\mathrm{S} \phi}{q^{2} m} .
$$

This shows that a very rapid change of the barometric pressure can not be recorded by the instrument, which may be easily supposed by common sence.

If $x$ and $r$ be small, but $m$ not so, then

$$
\Xi=\frac{\mathrm{V} \phi}{r} \frac{1}{\mathrm{P}_{0} \mathrm{~S} \sim \frac{q^{2} m \mathrm{~V}}{\mathrm{~S} \gamma}}\left(1-\frac{\frac{\mathrm{P}_{0} \mu r}{s}}{\mathrm{P}_{0} \mathrm{~S}-q^{2} \frac{m \mathrm{~V}}{\mathrm{~S} \gamma}}-\frac{1}{2} \frac{q^{2}\left(\frac{r \mathrm{~V}}{\mathrm{~S} \gamma}+\frac{\varkappa \mathrm{P}_{0} m}{\mathrm{~S}}\right)^{2}}{\left(\mathrm{P}_{0} \mathrm{~S}-q^{2} \frac{m \mathrm{~V}}{\mathrm{~S} \gamma}\right)^{2}}\right)
$$

If

$$
\mathrm{P}_{0} \mathrm{~S} \sim \frac{q^{2} m \mathrm{~V}}{\mathrm{~S} \gamma}
$$

be very near to zero, then the multiplication becomes very great, and therefore for such a barometric disturbance, whose $q$ is very near to

$$
\sqrt{\frac{\mathrm{PS}^{2} \gamma}{m \mathrm{~V}}}
$$

the barograph will record something next to nonsense. Thus in designing the instrument a proper caution must be taken to avoid common occurrence of such a case.

For $r=0$, the above equation reduces to

$$
\Xi=\frac{\mathrm{V} \phi}{\gamma} \frac{1}{\mathrm{P}_{0} \mathrm{~S} \sim \frac{q^{2} m \mathrm{~V}}{\mathrm{~S} \gamma}}\left\{1-\frac{1}{2} \frac{q^{2} \varkappa^{2} m^{2}}{\left(\mathrm{~S}^{2}-\frac{q^{2} m \mathrm{~V}}{\mathrm{P}_{0} \varkappa}\right)^{2}}\right\} .
$$

7. The phase difference $\varphi$ may be calculated by putting 


$$
\tan \varphi=\frac{\mathrm{B}}{\mathrm{A}}=\frac{q^{2}\left(\frac{r \mathrm{~V}}{\mathrm{~S} \gamma}+\frac{\mu \mathrm{P}_{0} m}{\mathrm{~S}}\right)}{-q \mathrm{P}_{0}\left(\frac{\varkappa r}{\mathrm{~S}}-\mathrm{S}\right)+q^{3} \frac{m \mathrm{~V}}{\mathrm{~S} \gamma}}
$$

Since $x$ and $r$ are very small, the retardation of the phase may not be striking.

If $r=0$, then

$$
\tan \varphi=\frac{q \varkappa \mathrm{P}_{0} m}{\mathrm{SP}_{0}+q^{2}-\frac{m \mathrm{~V}}{\mathrm{~S} \gamma}},
$$

and therefore the effect of the capillary tube on the phase retardation may be diminished by alleviating the belljar.

[Remark. If we put 1 in the places of $\gamma$ in all equations given above, we shall have the corresponding equations for isothermal change.],

In concluding this note, I must express my best thanks to Dr. Yoshida and to Prof. Dr. Okada. Dr. Yoshida, who has made some improvements to the Shaw-Dines microbarograph, called my attention to the work of the theoretical side, and I took the work in hand according to the suggestion of Prof. Dr. Okada.

25th. Aug. 1912.

Central Meteorological Observatory, Tôkyô. 